anales de psicología, 2018, vol. 34, $\mathrm{n}^{\circ} 1$ (january), 7-15 http://dx.doi.org/10.6018/analesps.34.1.278851
C Copyright 2018: Editum. Servicio de Publicaciones de la Universidad de Murcia. Murcia (Spain) ISSN print edition: 0212-9728. ISSN web edition (http://revistas.um.es/analesps): 1695-2294

\title{
Perceived discrimination, self-exclusion and well-being among people with HIV as a function of lipodystrophy symptoms
}

\author{
Maria J. Fuster-Ruiz de Apodaca ${ }^{1,2 *}$, Fernando Molero ${ }^{1}$, Eneko Sansinenea ${ }^{3}$, Francisco-Pablo Holgado ${ }^{4}$, \\ Alejandro Magallares ${ }^{1}$, and Arrate Agirrezabal ${ }^{5}$ \\ ${ }^{1}$ Departamento de Psicología Social y de las Organizaciones, Universidad Nacional de Educación a Distancia, UNED. \\ ${ }_{2}^{2}$ Sociedad Española Interdisciplinaria del Sida (SEISID A) (Spain) \\ ${ }^{3}$ Departamento de Personalidad, Evaluación y Tratamiento Psicológico, Universidad del País Vasco- Euskal Herriko Unibertsitatea (Spain) \\ ${ }^{4}$ Departamento de Metodología de Ciencias del Comportamiento y la Salud, UNED (Spain) \\ ${ }^{5}$ Departamento de Psicología Social y Metodología de Ciencias del Comportamiento, Universidad del País Vasco-Euskal Herriko Unibertsitatea (Spain)
}

\begin{abstract}
Título: Discriminación percibida, autoexclusión y bienestar entre las personas con VIH en función de los síntomas de la lipodistrofia.

Resumen: Este estudio examinó los efectos de la discriminación percibida sobre el bienestar de las personas con VIH y el papel mediador de la autoexclusión en función de los síntomas de lipodistrofia de los participantes. Se realizó un estudio ex post facto con una muestra de 706 personas con VIH. Se midió la autopercepción de lipoatrofia y lipohipertrofia, discriminación percibida, autoexclusión y bienestar psicológico. Los resultados de análisis de agrupamiento jerárquico mostraron que los participantes podían clasificarse en tres grupos: sin lipodistrofia, síndrome mixto con lipoacumulación predominante y lipoatrofia. Los resultados del modelado de ecuaciones estructurales revelaron que los efectos negativos de la discriminación percibida sobre el bienestar estaban mediados en gran medida por la autoexclusión. El análisis de invarianza reveló que el papel mediador de la autoexclusión no era el mismo en los tres grupos. Se confirmó la mediación completa de la autoexclusión en los grupos sin lipodistrofia y con lipoacumulación predominante. Con respecto a la lipoatrofia, los efectos negativos de la discriminación percibida fueron mayores y solo parcialmente mediados por la autoexclusión. En conclusión, tener lipodistrofia expone a las personas a más discriminación; la lipoatrofia fue la condición más estigmatizante.
\end{abstract}

Palabras clave: VIH; lipodistrofia; estigma; bienestar psicológico.

\section{Introduction}

The clinical presentation of body fat disorders is fat loss (lipoatrophy) and/or fat gain (lipohypertrophy) (Moreno et al., 2009). Lipoatrophy involves peripheral fat wasting, with loss of subcutaneous tissue in the face, arms, legs, and buttocks, whereas lipohypertrophy is characterized by the accumulation of abdominal visceral, breast, dorsocervical, or suprapubic fat. Several studies have reported that the combination of both syndromes is the most frequent condition, whilst isolated onset of the lipohypertrophy syndrome is the least frequent (Waters \& Nelson, 2007). Nowadays, the number of new cases of lipodystrophy has decreased significantly but the prevalence of the condition remains high, ranging from 13 to $70 \%$ in patients receiving antiretroviral treatment (Domingo et al., 2012). In Spain more than one half $(55 \%)$ of a sample of 965 patients reported changes in their body image (Cabrero et al., 2010). It is important to note that, once established, the lipodystrophy syndrome has limited reversibility (Cabrero et al., 2010).

Lipodystrophy may constitute a visible sign of HIV infection. In fact, several investigations have documented the

* Correspondence address [Dirección para correspondencia]:

María José Fuster-Ruiz de Apodaca, Ph.D., Juan del Rosal 10, 28040 Ma-

drid (Spain). E-mail: fuster.mariajose@gmail.com
Abstract: This study examined the effects of perceived discrimination on the well-being of people with HIV and the mediating role of self-exclusion as a function of the participants' symptoms of lipodystrophy. An ex post facto study with a sample of 706 people with HIV was conducted. Selfperception of lipoatrophy and lipohypertrophy, perceived discrimination, self-exclusion and psychological well-being were measured. Results of hierarchical cluster analysis showed participants could be categorized into three groups: no lipodystrophy, mixed syndrome with predominant lipoaccumulation and lipoatrophy. Results of structural equation modeling revealed that the negative effects of perceived discrimination on well-being were mediated to a large extent by self-exclusion. Invariance analysis revealed that the mediating role of self-exclusion was not the same in the three clusters. Complete mediation of self-exclusion in the groups without lipodystrophy and with predominant lipoaccumulation was confirmed. Regarding lipoatrophy, the negative effects of perceived discrimination were greater and only partly mediated by self-exclusion. In conclusion, having lipodystrophy exposed people to more discrimination; lipoatrophy was the most stigmatizing condition.

Keywords: HIV; lipodystrophy; stigma; psychological well-being.

association between lipodystrophy, stigma, and perceived discrimination. Stutterheim et al. (2011) found that participants with visible symptoms of HIV reported more stigma experiences than those who did not have visible symptoms. Similarly Herek et al. (2013) found that having more HIVrelated changes in physical appearance was associated with higher levels of perceived stigma.

These studies also found evidence of an association between visible physical symptoms and psychological wellbeing. Stutterheim et al. (2011) found that people with visible symptoms reported more psychological distress, lower self-esteem, and less social support. Herek et al. (2013) concluded that perceived stigma fully mediated the relationship between HIV-related body changes and depression and anxiety. Moreover, a recent study conducted in Spain has found that body disfigurement due lipodystrophy had harmful effects on the quality of life of people with HIV, in both its physical and mental dimensions (Ballester-Arnal et al., 2016).

Stigma and discrimination can also have indirect effects on the well-being of people with HIV through the coping strategies they use. They often employ avoidant coping strategies such as avoiding social contact (self-exclusion) or concealing their positive HIV status to avoid discrimination (Fuster-RuizdeApodaca et al., 2016; Herek et al., 2013; Miller, 2004). Avoidant coping not only has direct effects on 
well-being but also plays a mediational role in the negative effects of stigma on psychological well-being (Herek et al., 2013; Sanjuán et al., 2013).

Although Herek et al. (2013) and Stutterheim et al. (2011) analyzed discrimination and its effects on people with visible physical symptoms, they did not distinguish between the effects of the various morphological changes undergone by people with HIV who have lipodystrophy. However, this knowledge is important because it could lead to developing interventions to help patients with diverse body changes to cope with stigma. The present study is an attempt to bridge this gap. Through structural equation modeling we analyzed the effects of perceived discrimination and self-exclusion on the psychological well-being of people with HIV as a function of the physical changes associated with the participants' lipodystrophy. Based on the above evidence, we predicted that perceived discrimination would be negatively associated with psychological well-being and positively associated with self-exclusion, and that self-exclusion would be negatively associated with psychological well-being; thus self-exclusion would indirectly mediate the negative effects of perceived discrimination on psychological well-being. We also predicted that people with lipodystrophy, particularly lipoatrophy, would be more severely affected by discrimination (Peterson et al., 2008; Sanches et al., 2009).

\section{Method}

\section{Design and Participants}

A correlational ex post facto study was conducted in an incidental sample of 706 people with HIV. The eligibility criteria were: confirmed diagnosis of HIV-1 infection, age greater than 17 years and permanent residency in Spain. Sociodemographic and clinical data for the participants are shown in Table 1.

\section{Measures}

Self-perception of lipodystrophy. We used two items: "To what extent do you consider that: you lost fat in certain areas of the body (buttocks, arms, face, legs, etc.); you accumulated fat in certain areas of your body (abdomen, neck, back, etc.)?" These questions reflected the lipodystrophy symptoms assessed by the Assessment of Body Change and Distress (NIAID Adult AIDS Clinical Trials Group, 2001). Responses were given on a tenpoint scale, ranging from 1 (not at all) to 10 (a great deal).

Perceived discrimination and self-exclusion. We used items included in the Stigma Index for People Living with HIV developed by (UNAIDS, 2008). This Index has been translated into 54 languages, including Spanish, and 45.000 people with HIV from 50 countries have been interviewed (GNP+ et al., 2015). The Perceived Discrimination Scale was composed of seven items and the Self-exclusion scale of five items, rated on a four-point self-report scale (1 $=$ never, $4=$ always $)$. Both scales had satisfactory internal con- sistency (Cronbach's $\alpha=.76$ and $\alpha=.70$, respectively). Participants were also asked about their attributions for each one of the discrimination and self-exclusion items. These questions had three response options: attributed to HIV, to physical changes suffered due to lipodystrophy, and to other reasons.

Psychological well-being. We employed the twelveitem General Health Questionnaire (GHQ-12), using a fourpoint self-report scale, where higher scores indicated better psychological health. The validation data of this scale in Spain showed adequate internal consistency $(\alpha=.78)$ and evidence of criterion validity (Sánchez-López \& Dresch, 2008). This questionnaire has been used in Spain in population with HIV, displaying good psychometric properties and a higher mean of psychological discomfort than in general population (Muñoz-Moreno et al., 2014). In the present study, the scale showed high internal consistency (Cronbach's $\alpha=$.92).

Demographic and HIV-related data were also collected.

\section{Procedure}

Data were collected by the 26 NGOs and 22 hospitals involved in the study. During their clinical appointments or when attending to diverse services offered by NGOs, professionals from these centers explained the goals of the study to the participants, requesting their participation and obtaining their informed consent. The self-administered questionnaire took approximately 20 minutes to complete. Participants were ensured about the confidentiality of the data.

Ethical approval was granted by the ethical committee of the Coordinadora Estatal de VIH-Sida [Spanish HIV-AIDS Coordinator]. Permission to conduct the research was granted by the NGOs and hospitals involved in the study. The survey was conducted in accordance with the principles of the Helsinki Declaration and its amendments. Data were collected between January and March 2010.

\section{Data Analysis}

First, exploratory analysis was performed. The mean proportions of missing data from incomplete cases for each scale were .01, .01, and .02, for the Perceived Discrimination, Self-exclusion, and Psychological Well-being Scales, respectively. The items on perceived lipoatrophy and perceived lipoaccumulation were not completed by 3.8\% and $4.1 \%$ of participants, respectively. No consistent pattern in missing cases was observed either at the case or item level, so we used a random procedure that took into account the mean and standard deviation of the items to impute missing values. This procedure was conducted as a function of the participant's cluster. Missing data on perceived lipoatrophy and perceived lipoaccumulation were not imputed. A total of 673 valid cases remained for analysis.

Next, we performed hierarchical cluster analysis to group 
participants according to their lipodystrophy symptoms. Three clusters were specified in the analysis procedure, this number was selected on the basis of evidence about the diversity of symptoms (Moreno et al., 2009; Waters \& Nelson, 2007).

The model was analyzed using structural equation modeling (SEM). We also analyzed its invariance among the clusters found. Because the data were ordinal and did not meet the normality assumption, we used the robust unweighted least squares method. Goodness of fit was assessed using the following indices: Satorra-Bentler chi square, chi-squaredegree of freedom ratio, goodness of fit index (GFI), adjusted goodness of fit index $(A G F I)$, root mean square error of approximation (RMSEA), standardized root mean square residual (SRMR), comparative fit index (CFI) and nonormed fit index (NNFI). We also used the expected cross validation index (ECVI) to compare alternative models and the Root Deterioration per Restriction Index (RDR) (Browne \& Du Toit, 1992), whose values have a similar interpretation as RMSEA.

The programs used were PRELIS 2.30, LISREL 8.7, and SPSS 15.

\section{Results}

\section{Hierarchical Cluster Analysis}

Participants were classified into three groups according to their perceived lipoatrophy and lipohypertrophy scores. Clusters based on perceived lipoatrophy, $F(2,670)=780.77$, $p=.000$, and perceived lipohypertrophy, $F(2,670)=$ $1117.39, p=.000$, were identified effectively.

The first cluster (C1: 'no lipodystrophy') was made up of 314 participants with very low scores for perceived lipoatrophy and perceived lipohypertrophy $(M=1.7, S D=1.04 ; M$ $=1.8, S D=1.3$, respectively; $d=-0.04)$. The second cluster (C2: 'predominant lipoaccumulation') consisted of 200 peo- ple reporting symptoms of both lipoatrophy and lipohypertrophy, although perceived lipohypertrophy scores were higher $(M=6.2, S D=2.4 ; M=7.7, S D=1.6$, respectively; $d=-0.72$ ). The third cluster (C3: 'lipoatrophy') was made up of 159 participants who had high perceived lipoatrophy scores and low lipohypertrophy scores $(M=7.4, S D=1.8$; $M=2.3, S D=1.4$, respectively; $d=3.08$ ). Figure 1 presents the distribution of the means of the two symptoms of lipodystrophy in the three clusters.

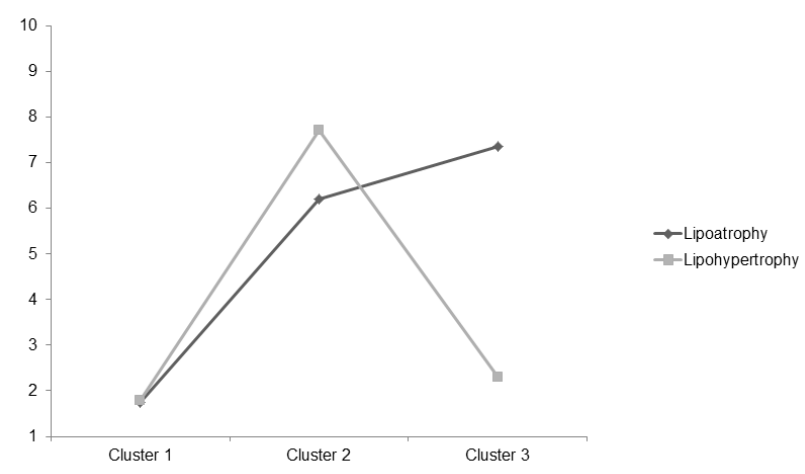

Figure 1. Mean perceived lipoatrophy and perceived lipohypertrophy in the three clusters of participants.

Cluster 1 = people without lipodystrophy; Cluster 2 = people with predominant lipoaccumulation; Cluster 3 = people with high lipoatrophy.

The sociodemographic and health characteristics of the clusters are shown in Table 1 . Cluster 1 was characterized by greater youth, a shorter duration of infection, and transmission through sexual intercourse. Cluster 2 had a higher proportion of women than the other two clusters and was also characterized by transmission through sexual intercourse. Cluster 3 had a higher proportion of older, heterosexual men, who had been infected for a longer time and had acquired HIV from sharing needles.

$\underline{\text { Table 1. Sociodemographic and clinical characteristics of the participants. }}$

\begin{tabular}{|c|c|c|c|c|}
\hline & $\begin{array}{c}\text { Total } \\
(N=673)\end{array}$ & $\begin{array}{c}\text { C1 } \\
(n=314)\end{array}$ & $\begin{array}{c}\text { C2 } \\
(n=200)\end{array}$ & $\begin{array}{c}\text { C3 } \\
(n=159)\end{array}$ \\
\hline \multicolumn{5}{|l|}{ Gender } \\
\hline Males & 70.8 & 74.5 & 58.4 & 79.7 \\
\hline Females & 28.2 & 25.5 & 39.6 & 18.4 \\
\hline Transsexual & 1.0 & -- & 2 & 1.9 \\
\hline \multicolumn{5}{|l|}{ Age in years $(\mathrm{M} \pm S D)$} \\
\hline Total sample & $43.1 \pm 7.6$ & $42 \pm 8.6$ & $43.7 \pm 6.1$ & $45 \pm 6.9$ \\
\hline Men & $43.3 \pm 7.7$ & $42.2 \pm 8.7$ & $44 \pm 6.3$ & $44.8 \pm 7$ \\
\hline Women & $42.9 \pm 7.1$ & $41.5 \pm 8.4$ & $43.5 \pm 5.2$ & $46.2 \pm 6.4$ \\
\hline \multicolumn{5}{|l|}{ Educational level } \\
\hline No studies & 4.8 & 4.2 & 6.1 & 3.8 \\
\hline Primary education & 41.1 & 38.6 & 41.6 & 49.4 \\
\hline Secondary education & 35.3 & 35.4 & 34.5 & 32.1 \\
\hline University degree & 18.4 & 21.4 & 16.8 & 14.7 \\
\hline Other & 0.4 & .03 & 1 & -- \\
\hline \multicolumn{5}{|l|}{ Marital status } \\
\hline Married/living with a partner & 31.1 & 33.2 & 31.5 & 26.1 \\
\hline Divorced/separated & 17.2 & 17.3 & 17.3 & 19.7 \\
\hline Single & 45.4 & 45.3 & 41.6 & 47.1 \\
\hline
\end{tabular}




\begin{tabular}{|c|c|c|c|c|}
\hline & $\begin{array}{c}\text { Total } \\
(N=673)\end{array}$ & $\begin{array}{c}\text { C1 } \\
(n=314)\end{array}$ & $\begin{array}{c}\mathrm{C} 2 \\
(n=200)\end{array}$ & $\begin{array}{c}\text { C3 } \\
(n=159)\end{array}$ \\
\hline Widowed & 6.2 & 4.2 & 9.6 & 7 \\
\hline \multicolumn{5}{|l|}{ Sexual behaviour } \\
\hline Heterosexual & 61.2 & 57.2 & 64.3 & 66 \\
\hline Homosexual & 26.7 & 33.1 & 21.9 & 19.2 \\
\hline Bisexual & 6.8 & 5.1 & 7.7 & 9 \\
\hline No response given & 5.3 & 4.5 & 6.1 & 5.8 \\
\hline \multicolumn{5}{|l|}{ Transmission route } \\
\hline Unprotected sexual intercourse & 51.7 & 58.8 & 50.3 & 38.3 \\
\hline Sharing of injecting materials & 27.8 & 21.8 & 29.2 & 39.6 \\
\hline Transfusion & 1.3 & 1.9 & 0.5 & 1.3 \\
\hline Unknown & 17.8 & 15.9 & 19 & 19.5 \\
\hline Other & 1.5 & 1.6 & 1 & 1.3 \\
\hline $\begin{array}{l}\text { Duration of infection in years } \\
(\mathrm{M} \pm S D)\end{array}$ & $13.7 \pm 7.9$ & $11.3 \pm 8.2$ & $15.8 \pm 6.5$ & $16.7 \pm 6.7$ \\
\hline $\begin{array}{l}\mathrm{CD} 4 \text { cell count in cells } / \mathrm{mm}^{3} \\
(\mathrm{M} \pm S D)\end{array}$ & $521.3 \pm 313.3$ & $556.4 \pm 342.7$ & $528 . \pm 294.7$ & $546.2 \pm 286.9$ \\
\hline Undetectable plasma viral load & 84.2 & 79.3 & 90.5 & 88.1 \\
\hline
\end{tabular}

Model Testing: The Influence of Perceived Discrimination and Self-Exclusion on Psychological WellBeing

Results of the model testing showed a good fit to the data (Table 2). All the lambda coefficients were higher than 0.5 , the level considered adequate (Green, 1978).
The structural model indicated a positive association between perceived discrimination and self-exclusion, and a negative association between self-exclusion and psychological well-being. The negative association between perceived discrimination and psychological well-being was nonsignificant. Table 3 presents the fully standardized solution for the hypothetical model.

Table 2. Fit indexes of the hypothesized model and the model in the three clusters.

\begin{tabular}{|c|c|c|c|c|c|c|c|c|c|}
\hline & RMSEA $[90 \% \mathrm{CI}]$ & SRMR & GFI & $A G F I$ & CFI & NNFI & Satorra-Bentler $\chi^{2}$ & $d f$ & $\chi^{2 / d f}$ \\
\hline Model in the total sample & $\begin{array}{c}.045 \\
{[.041, .050]}\end{array}$ & .050 & 99 & .98 & .99 & .99 & $\begin{array}{c}610.45 \\
(p=.000)\end{array}$ & 249 & 2.45 \\
\hline Model in cluster 1 & $\begin{array}{c}.039 \\
{[.030, .047]}\end{array}$ & .062 & .98 & .97 & .99 & .99 & $\begin{array}{c}368.79 \\
(p=.000)\end{array}$ & 249 & 1.48 \\
\hline Model in cluster 2 & $\begin{array}{c}.043 \\
{[.031, .054]}\end{array}$ & .062 & .97 & .97 & .99 & .99 & $\begin{array}{c}341.74 \\
(p=.000)\end{array}$ & 249 & 1.37 \\
\hline Model in cluster 3 & $\begin{array}{c}035 \\
{[.016, .049]}\end{array}$ & .082 & .96 & .95 & .99 & .99 & $\begin{array}{c}297.85 \\
(p=.000) \\
\end{array}$ & 249 & 1.19 \\
\hline
\end{tabular}

Note. Cluster 1 = people without lipodystrophy; Cluster 2 = people with predominant lipoaccumulation; Cluster $3=$ people with high lipoatrophy.

Mediation analysis. To determine the extent of the mediation role of self-exclusion, we performed stepwise mediation analysis. The first step was to show that the association between perceived discrimination and psychological well-being was significant. When all the indirect paths in the model $\left(\beta_{12}\right.$ and $\gamma_{21}$ ) were set to 0 , the direct path from perceived discrimination to psychological well-being was significant and negative $(\beta=-.44)$. The next step was to determine whether values of self-exclusion are predicted by perceived discrimination, and whether self-exclusion predicted psychological well-being. For this purpose, we allowed the indirect paths $\left(\beta_{12}\right.$ and $\left.\gamma_{21}\right)$ to vary. Figure 2 shows that the coefficient of the direct path from perceived discrimination to psychological well-being $\left(\gamma_{11}\right)$ was greatly reduced (from -.44 to -.11). For the sake of clarity, observed variables were omitted from the figure. This step produced a significant improvement in the fit of the model, $\Delta \chi^{2}(2, N=706)=106.37, p=$ $.00, \Delta S R M R=.12, \Delta C F I=.01$, suggesting that the relationship between perceived discrimination and psychological well-being was largely mediated by self-exclusion. 
Table 3. Fully standardized solution of the model for all the participants and for each one of the three clusters.

\begin{tabular}{|c|c|c|c|c|c|c|c|c|c|c|c|c|}
\hline & \multicolumn{4}{|c|}{ Discrimination } & \multicolumn{4}{|c|}{ Self-Exclusion } & \multicolumn{4}{|c|}{ Psychological Well-Being } \\
\hline & $\mathrm{T}$ & $\mathrm{C} 1$ & $\mathrm{C} 2$ & $\mathrm{C} 3$ & $\mathrm{~T}$ & $\mathrm{C} 1$ & $\mathrm{C} 2$ & $\mathrm{C} 3$ & $\mathrm{~T}$ & $\mathrm{C} 1$ & $\mathrm{C} 2$ & $\mathrm{C} 3$ \\
\hline \multicolumn{13}{|l|}{ Discrimination } \\
\hline Social activities & .78 & .81 & .87 & .58 & & - & - & - & & - & - & - \\
\hline Activities with relatives & .72 & .70 & .74 & .58 & & - & - & - & & - & - & - \\
\hline Comments, gossip & .78 & .77 & .76 & .69 & & - & - & - & & - & - & - \\
\hline Insults, threats & .70 & .64 & .69 & .84 & & - & - & - & & - & - & - \\
\hline By people with HIV & .56 & .60 & .58 & .37 & & - & - & - & & - & - & - \\
\hline At work & .66 & .69 & .56 & .68 & & - & - & - & & - & - & - \\
\hline At health service & .55 & .56 & .50 & .33 & & - & - & - & & - & - & - \\
\hline \multicolumn{13}{|l|}{ Self-exclusion } \\
\hline Social gatherings & & - & - & - & .68 & .61 & .77 & .61 & & - & - & - \\
\hline Isolation from family \& friends & & - & - & - & .80 & .79 & .82 & .76 & & - & - & - \\
\hline Quitting work & & - & - & - & .60 & .62 & .62 & .49 & & - & - & - \\
\hline Not seeking work & & - & - & - & .67 & .77 & .64 & .52 & & - & - & - \\
\hline Intimate relationships & & - & - & - & .54 & .52 & .48 & .59 & & - & - & - \\
\hline \multicolumn{13}{|l|}{ Psychological well-being } \\
\hline Ability to concentrate & & & & & & & & & .65 & .68 & .64 & .59 \\
\hline Usefulness in life & & - & - & - & & - & - & - & .72 & .73 & .74 & .70 \\
\hline Decision-making capacity & & - & - & - & & - & - & - & .68 & .73 & .67 & .59 \\
\hline Capacity for enjoyment & & - & - & - & & - & - & - & .76 & .78 & .66 & .81 \\
\hline Coping with problems & & - & - & - & & - & - & - & .76 & .81 & .74 & .71 \\
\hline Happiness & & - & - & - & & - & - & - & .74 & .76 & .70 & .73 \\
\hline Inability to overcome difficulties & & - & - & - & & - & - & - & .76 & .74 & .82 & .76 \\
\hline Loss of self-confidence & & - & - & - & & - & - & - & .86 & .82 & .90 & .87 \\
\hline Feeling good for nothing & & - & - & - & & - & - & - & .86 & .85 & .83 & .87 \\
\hline Insomnia & & - & - & - & & - & - & - & .60 & .60 & .58 & .58 \\
\hline Tension & & - & - & - & & - & - & - & .72 & .71 & .72 & .75 \\
\hline Depression & & - & - & - & & - & - & - & .79 & .79 & .75 & .84 \\
\hline \multicolumn{13}{|l|}{ Structural model } \\
\hline Discrimination & & & & & .66 & .63 & .68 & .53 & $-.11^{1}$ & $-.07^{1}$ & $.04^{1}$ & -.37 \\
\hline Self-Exclusion & & & & & & & & & -.50 & -.56 & -.59 & -.26 \\
\hline
\end{tabular}

Note. $\mathrm{T}=$ total sample; $\mathrm{C} 1=$ people without lipodystrophy; $\mathrm{C} 2=$ people with predominant lipoaccumulation; $\mathrm{C} 3=$ people with high lipoatrophy. ${ }^{1}$ Nonsignificant paramemeters. All the remaining parameters are significant $(\mathrm{p}<.05)$.
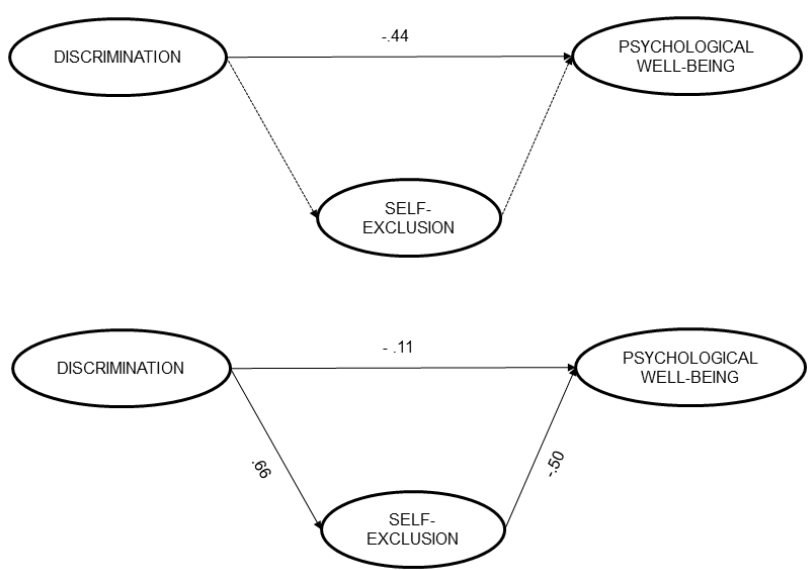

Figure 2. Steps of mediation analysis in the total sample. Dotted lines represent path coefficients set to 0 .

\section{Cluster Invariance}

Next, we analyzed the goodness of fit of the model for the three clusters of participants. The results indicated that the fit of the model was good for all three groups (Table 2). The fully standardized solutions are shown in Table 3.

Invariance of the measurement model. Item-by-item verification of group differences in lambda coefficients revealed differences in having suffered insults and threats, discrimination at work, denial of healthcare services, avoiding social gatherings and intimate relationships (Table 4). The model was fairly stable with regard to psychological wellbeing.

Invariance of the structural model. We found that the structural model as a whole was not invariant. Significant differences in the direct relationship between perceived discrimination and psychological well-being were observed. We also found marginal differences in the relationship between perceived discrimination and self-exclusion, as well as in the relationship between self-exclusion and psychological wellbeing (Table 4).

Examination of the coefficients revealed that the direct association between perceived discrimination and psychological well-being was higher in C3, but was nonsignificant in the other two groups. In C3, the influence of perceived discrimination on self-exclusion and the influence of selfexclusion on psychological well-being were lower than in the other two groups (Table 4). These results indicated that the mediating role of self-exclusion was not the same in the three clusters of participants (Figure 3). In C1 and in C2, the effects of perceived discrimination on psychological wellbeing were largely mediated by self-exclusion. Complete mediation of self-exclusion in these two clusters was confirmed. There was a significant improvement in the fit of the model when the mediation relationship was introduced, C1: $\Delta \chi^{2}(2, N=314)=37.83, p=.00 ; \mathrm{C} 2: \Delta \chi^{2}(2, N=200)=$ $25.84, p=.00$; and the change in chi-square was nonsignificant when only the direct association between perceived discrimination and psychological well-being was set to $0, \mathrm{C} 1$ : $\Delta \chi^{2}(1, N=314)=1.36, p=.24 ; \mathrm{C} 2: \Delta \chi^{2}(1, N=200)=1.36$, $p=.25$. 
Table 4. Invariance of the measurement model and the structural model in the three clusters.

\begin{tabular}{|c|c|c|c|c|c|c|c|c|}
\hline & $\chi^{2}\left(\Delta \chi^{2}\right)$ & $d f(\Delta d f)$ & ECVI & RMSEA & $S R M R$ & CFI & GFI & $R D R$ \\
\hline Equivalence (Model 1) & 1017.74 & 747 & 1.98 & .040 & .082 & .99 & .96 & -- \\
\hline Invariance measurement model (Model 2) & $(79.71)^{* * *}$ & $(42)$ & 1.97 & .042 & .094 & .99 & .94 & .039 \\
\hline \multicolumn{9}{|l|}{ Discrimination } \\
\hline$\lambda \mathrm{x}_{21}$ Family & $(1.64)$ & (2) & 1.98 & .040 & .082 & .99 & .96 & 0 \\
\hline$\lambda \mathrm{x}_{31}$ Comments, gossip & $(4.7)$ & (2) & 1.98 & .040 & .082 & .99 & .96 & 0 \\
\hline$\lambda \mathrm{x}_{41}$ Insults, threats & $(12.18)^{* * *}$ & (2) & 1.99 & .041 & .086 & .99 & .95 & .10 \\
\hline$\lambda \mathrm{x}_{51}$ People with HIV & $(2.93)$ & (2) & 1.98 & .040 & .082 & .99 & .96 & 0 \\
\hline$\lambda \mathrm{x}_{61}$ At work & $(9.4)^{* *}$ & (2) & 1.99 & .041 & .083 & .99 & .95 & .10 \\
\hline$\lambda \mathrm{x}_{71}$ Health service & $(4.98) \dagger$ & (2) & 1.98 & .040 & .082 & .99 & .96 & .071 \\
\hline \multicolumn{9}{|l|}{ Self-exclusion } \\
\hline$\lambda \mathrm{y}_{132}$ Social gatherings & $(6.96)^{*}$ & (2) & 1.98 & .041 & .082 & .99 & .96 & .071 \\
\hline$\lambda \mathrm{y}_{142}$ Isolation from family $\&$ friends & $(4.59)$ & (2) & 1.98 & .040 & .082 & .99 & .96 & 0 \\
\hline$\lambda \mathrm{y}_{162}$ Quitting work & $(2.21)$ & (2) & 1.98 & .040 & .082 & .99 & .96 & 0 \\
\hline$\lambda y_{172}$ Intimate relationships & $(7.49)^{*}$ & (2) & 1.98 & .041 & .083 & .99 & .95 & .071 \\
\hline \multicolumn{9}{|l|}{ Psychological well-being } \\
\hline$\lambda y_{12}$ Usefulness in life & $(1.59)$ & (2) & 1.98 & .040 & .082 & .99 & .96 & 0 \\
\hline$\lambda \mathrm{y}_{13}$ Decision-making capacity & $(1.9)$ & (2) & 1.98 & .040 & .082 & .99 & .96 & 0 \\
\hline$\lambda y_{14}$ Capacity for enjoyment & $(5.13) \dagger$ & (2) & 1.98 & .040 & .084 & .99 & .96 & .10 \\
\hline$\lambda \mathrm{y}_{15}$ Coping with problems & $(1.81)$ & (2) & 1.98 & .040 & .082 & .99 & .96 & 0 \\
\hline$\lambda \mathrm{y}_{16}$ Happiness & $(2.03)$ & (2) & 1.98 & .040 & .082 & .99 & .96 & 0 \\
\hline$\lambda \mathrm{y}_{17}$ Inability to overcome difficulties & $(3.89)$ & (2) & 1.98 & .040 & .082 & .99 & .96 & 0 \\
\hline$\lambda \mathrm{y}_{18}$ Loss of self-confidence & $(4.3)$ & (2) & 1.98 & .040 & .082 & .99 & .96 & 0 \\
\hline$\lambda \mathrm{y}_{19}$ Feeling good for nothing & $(3.71)$ & (2) & 1.98 & .040 & .082 & .99 & .96 & 0 \\
\hline$\lambda y_{110}$ Insomnia & $(2.87)$ & (2) & 1.98 & .040 & .082 & .99 & .96 & 0 \\
\hline$\lambda y_{111}$ Tension & $(5.5) \dagger$ & $(2)$ & 1.98 & .040 & .082 & .99 & .96 & .071 \\
\hline$\lambda y_{112}$ Depression & $(2.59)$ & (2) & 1.98 & .040 & .082 & .99 & .96 & 0 \\
\hline Invariance of structural model (Model 3) & $(12.75)^{*}$ & (6) & 1.98 & .041 & .086 & .99 & .95 & .057 \\
\hline Discrimination-Psychological well-being & $(8.09)^{*}$ & (2) & 1.98 & .041 & .085 & .99 & .95 & .071 \\
\hline Discrimination-Self-exclusion & $(5.37) \dagger$ & (2) & 1.98 & .040 & .082 & .99 & .96 & .071 \\
\hline Self-exclusion-Psychological well-being & $(4.9) \dagger$ & $(2)$ & 1.98 & .041 & .082 & .99 & .96 & .071 \\
\hline
\end{tabular}

Note. $\Delta \chi^{2}$ (change in $\chi^{2}$ with regard to Model 1). $\Delta d f$ (change in degrees of freedom). C1 = people without lipodystrophy; C2 $=$ people with predominant lipoaccumulation; $\mathrm{C} 3=$ people with high lipoatrophy. $p<.1 ;{ }^{*} p<.05 ;{ }^{* *} p<.01 ; * * * p<.0001$.
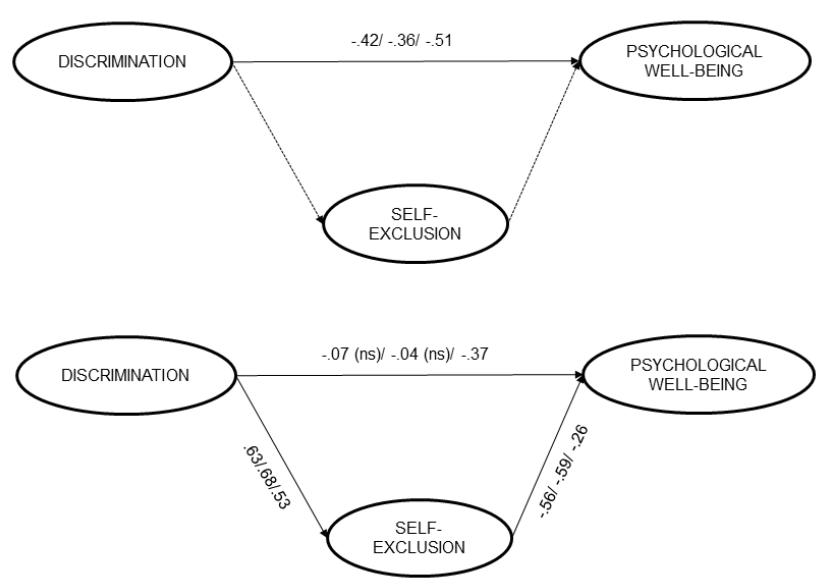

Figure 3. Steps in the mediation analysis for the three clusters.

Cluster 1/ Cluster 2/ Cluster 3. Dotted lines represent path coefficients set to 0 .

However, in C3, perceived discrimination produced effects on psychological well-being both directly and through its effect on self-exclusion (Figure 3). In this group, selfexclusion was a partial mediator of the effects of perceived discrimination on psychological well-being. In contrast to the other two groups, the improvement in the fit of the model when introducing the mediation relationship was nonsignificant, $\Delta \chi^{2}(2, N=159)=2.76, p=.25$. The fit of the model also worsened significantly when the direct association between perceived discrimination and psychological well-being was set to $0, \Delta \chi^{2}(1, N=159)=7.61, p=.01$. The total impact of perceived discrimination on well-being was highest (-.51) in the C3 group. For clarity, only the structural model is shown in Figure 3.

\section{Attributions of perceived discrimination and self- exclusion}

HIV was the main cause why participants believed they had been discriminated or why they self-excluded themselves (39.5 and 45.8\%, respectively). The percentage of people who attributed perceived discrimination to lipodystrophy $(29.3 \%)$ was higher than that of the people who indicated lipodystrophy as a cause of self-exclusion (18.6\%). Lastly, $31.2 \%$ attributed discrimination and $34.8 \%$ attributed self-exclusion to other causes.

To verify possible differences between the clusters, we created a quantitative variable, counting the presence of attributions to each cause (HIV, lipodystrophy and other 
causes) in each of items of the discrimination and selfexclusion scale. ANOVA only yielded significant differences between the clusters in the participants' attributions to lipodystrophy, both of perceived discrimination, $F(2,670)=$ $34.83, p=.000, \eta^{2}=.09$, and of self-exclusion, $F(2,670)=$ $37.97, p=.000, \eta^{2}=.10$. In the case of discrimination, the Tukey HSD test showed that the people of Clusters 2 and 3 (lipoaccumulation and lipoatrophy) attributed perceived discrimination to lipodystrophy to a greater extent than those of Cluster 1 (no lipodystrophy). In the case of self-exclusion, the people from Cluster 1 attributed it to lipodystrophy to a lesser extent, whereas those from Cluster 2 attributed it to a greater extent to lipodystrophy.

\section{Discussion}

The main assumption of this study was that the existence of body fat disorders may have different effects on perceived discrimination, well-being, and coping strategies in people with HIV. Participants in this study could be classified into three groups: a group without lipodystrophy, a group with mixed lipodystrophy in which lipoaccumulation was predominant, and a group affected only by lipoatrophy. These groups also differed in the sociodemographic profile. The cluster profile found was consistent with the empirical evidence showing that there are certain risk factors related to the patient and to exposure to antiretroviral drugs (age, sex, time elapsed since diagnosis, and long exposure to certain antiretroviral drugs) that are associated with the development of lipoatrophy and lipohypertrophy (Cabrero et al., 2010; Domingo et al., 2012; Moreno et al., 2009).

Results of model testing showed that perceived discrimination had negative effects on the psychological well-being of all participants, a finding consistent with early exploratory studies (Herek et al., 2013; Schmitt et al., 2014). Results also showed that these negative effects were mediated by selfexclusion behaviors that people with HIV use to avoid discrimination. However, the relationship between perceived discrimination, use of self-exclusion strategies, and psychological well-being varied according to cluster membership.

In the groups without lipodystrophy or with predominant lipoaccumulation, the effect of perceived discrimination on psychological well-being was totally mediated by the use of self-exclusion strategies. This may be because these groups are able to conceal their HIV status, as people without lipodystrophy show few visible signs of the infection, and the body shape of people with predominant lipoaccumulation is not strongly associated with HIV. In these groups, the negative effects of perceived discrimination on psychological well-being were associated with the behaviors they performed to avoid discrimination, rather than to discrimination per se. Self-exclusion is a way of avoidance coping that may impact negatively on well-being (Schmitt et al., 2014; Stutterheim et al., 2011). However, the reasons for using self-exclusion strategies in these two groups may differ.

The group of participants without lipodystrophy had been infected for less time and there is evidence showing that less experience with the illness may lead to less effective coping (Moskowitz et al., 2009). Moreover, this cluster had a higher percentage of homosexuals than the other clusters. Some research shows that homosexual men perceive public stigma as overlapping with the association between HIV and homosexuality (Berg \& Ross, 2014; Smit et al., 2012). These factors can lead them to conceal their condition and to avoid certain situations.

The group with predominant lipoaccumulation had a higher percentage of women than the other groups. Previous studies have documented the fact that women with HIV are more vulnerable to the effects of lipohypertrophy and suffer from more distress than men (Domingo et al., 2012; Gordillo et al., 2009). Furthermore, there is evidence that women suffer more overweight than men (Nguyen \& ElSerag, 2010). Thus, the stigma suffered by this group may be associated with something other than HIV, for example, the stigma associated with overweight. This might explain why, in this group, avoidance of social gatherings made a greater contribution to self-exclusion than in the other groups.

Finally, the effects of perceived discrimination on the lipoatrophy group were different. The negative effect of perceived discrimination on psychological well-being was highest in this group, and the mediating role of selfexclusion was smaller. This may be because this group shows an observable body shape that many people associate with HIV (thinness) and in consequence, they may be suffering the HIV-related stigma. In Spain, prejudice, discrimination, and feelings of fear, anger, and disgust towards people with HIV have been documented (Fuster-RuizdeApodaca et al., 2014). In fact, results of the analysis of the measurement model showed that insults and threats made a greater contribution to perceived discrimination in this group than in the other groups. These results are consistent with studies indicating that facial lipoatrophy is the main source of psychological problems and exposure to stigma in people with HIV (Sanches et al., 2009; Waters \& Nelson, 2007). Additionally, this group was composed of a higher percentage of people who acquired the infection by sharing needles than the other groups. Thus, the causes of discrimination and the participants' attributions of discrimination might overlap. Overlapping stigmas (HIV and drug use) could be related to the greater harmful effects of perceived discrimination in this group. In fact, the existing literature has shown the complexity and damaging effects of intersectional stigma (Chambers et al., 2015).

To shed light on the reasons for the perceived discrimination and self-exclusion, results also showed that the participants attributed them mainly to HIV. However, differences were only found between the clusters in attributions to lipodystrophy as the cause of perceived discrimination and of self-exclusion. People with no physical bodily changes attributed perceived discrimination to lipodystrophy the least, whereas people with predominant lipoaccumulation pointed to it as the reason for their self-exclusion. These results sup- 
port the conclusions derived from the differences in the analyzed model.

\section{Conclusions}

In conclusion, this study provides evidence that the type of lipodystrophy, conjointly with certain sociodemographic profiles, is an important factor in an individual's experience of discrimination. This finding is novel because, to our knowledge, the existing studies have not analyzed how different physical changes affect the experience of stigma and well-being. Our results may be useful for the development of interventions to reduce discrimination and self-exclusion and to help people with HIV to cope with them. The nature of the interventions must differ as a function of whether or not the participants have lipodystrophy and the type of symptoms they present. In people without lipodystrophy or with predominant lipoaccumulation, psychosocial interventions aimed at decreasing the use of avoidance strategies would be useful. In the case of people with lipoatrophy, it

\section{References}

Ballester-Arnal, R., Gómez-Martínez, S., Fumaz, C. R., González-García, M., Remor, E., \& Fuster, M. J. (2016). A Spanish study on psychological predictors of quality of life in people with HIV. AIDS and Behavior, 20(281-291), Advance online publication. http://doi.org/10.1007/s10461-015-1208-6

Berg, R. C., \& Ross, M. W. (2014). The second closet: A qualitative study of HIV stigma among seropositive gay men in a southern US city. International Journal of Sexual Health, 26(3), 186-199. http://doi.org/10.1080/19317611.2013.853720

Browne, M. W., \& Du Toit, S. H. (1992). Automated fitting of nonstandard models. Multivariate Behavioral Research, 27(2), 269-300. http://doi.org/10.1207/s15327906mbr2702_13

Cabrero, E., Griffa, L., \& Burgos, A. (2010). Prevalence and impact of body physical changes in HIV patients treated with highly active antiretroviral therapy: results from a study on patient and physician perceptions. AIDS Patient Care and STDs, 24(1), 5-13. http://doi.org/10.1089/apc.2009.0191

Chambers, L. A., Rueda, S., Baker, D. N., Wilson, M. G., Deutsch, R. Raeifar, E., ... The Stigma Review Team. (2015). Stigma, HIV and health: A qualitative synthesis. BMC Public Health, 15(1), 848. http://doi.org/10.1186/s12889-015-2197-0

Domingo, P., Estrada, V., López-Aldeguer, J., Villaroya, F., \& Martínez, E. (2012). Fat redistribution syndromes associated with HIV-1 infection and combination antiretroviral therapy. AIDS Reviews, 14(2), 112-123.

Fuster-RuizdeApodaca, M. J., Molero, F., Gil de Montes, L., Agirrezabal, A., Toledo, J., \& Jaen, A. (2014). Evolution of HIV-related stigma in Spain between 2008 and 2012. AIDS Care, 26(sup1), S41-S45. http://doi.org/10.1080/09540121.2014.906557

Fuster-RuizdeApodaca, M. J., Molero, F., \& Ubillos, S. (2016). Assessment of an intervention to reduce the impact of stigma on people with HIV, enabling them to cope with it. Anales de Psicología, 32(1), 39-48. http://doi.org/10.6018/analesps.32.1.192121

GNP+, ICW, \& UNAIDS. (2015). The people living with HIV stigma index. Retrieved from http://www.stigmaindex.org/

Gordillo, V., Fekete, E. M., Platteau, T., Antoni, M. H., Schneiderman, N., \& Nöstlinger, C. (2009). Emotional support and gender in people living with HIV: Effects on psychological well-being. Journal of Behavioral Medicine, 32(6), 523-531. http://doi.org/10.1007/s10865-009-9222-7

Green, P. (1978). Analyzing multivariate data. Hinsdale, IL: Dryden Press. would be more useful to train them in the use of approach coping strategies, that is, to change the objective situation and their reactions to it. Another useful intervention would be to alleviate their symptoms through cosmetic medicine or plastic surgery. In any case, interventions to decrease public stigma associated with HIV are necessary.

This study is subject to some limitations. Although the use of confirmatory methodology represents an advance over previous studies, the cross-sectional design does not permit causal inferences. Experimental studies should be used to confirm our tentative explanations of the results. Another limitation is that the index of lipodystrophy was based on participants' perceptions. However, other studies using similar measures found no significant differences between patients' perceptions of lipodystrophy and doctoradministered assessments (Cabrero et al., 2010).

\section{List of abbreviations}

NGO Non-governmental organization
Herek, G. M., Saha, S., \& Burack, J. (2013). Stigma and psychological distress in people with HIV/AIDS. Basic and Applied Social Psychology, 35 41-54. http://doi.org/10.1080/01973533.2012.746606

Miller, C. T. (2004). Social psychological perspectives on coping with stressors related to stigma. In S. Levin \& C. van Laar (Eds.), Stigma and group inequality (pp. 21-44). Mahwah, NJ: Erlbaum.

Moreno, S., Miralles, C., Negredo, E., Domingo, P., Estrada, V., Gutiérrez, F., ... Martínez, E. (2009). Disorders of body fat distribution in HIV-1infected patients. AIDS Reviews, 11(3), 126-134.

Moskowitz, J. T., Hult, J. R., Bussolari, C., \& Acree, M. (2009). What works in coping with HIV? A meta-analysis with implications for coping with serious illness. Psychological Bulletin, 135(1), 121-141. http://doi.org/10.1037/a0014210

Muñoz-Moreno, J. A., Fuster-RuizdeApodaca, M. J., Fumaz, C. R., Ferrer, M. J., Molero, F., Jaen, À., ... Dalmau, D. (2014). Quejas cognitivas en personas con infección por el virus de la inmunodeficiencia humana en España: Prevalencia y variables relacionadas [Cognitive complaints in people with human immunodeficiency virus in Spain: Prevalence and related variables]. Medicina Clínica, 142, 438-444. http://doi.org/10.1016/j.medcli.2013.02.037

Nguyen, D., \& El-Serag, H. (2010). The epidemiology of obesity. Gastroenterology Clinics of North America, 39, 1-7. http://doi.org/10.1016/j.gtc.2009.12.014

NIAID Adult AIDS Clinical Trials Group. (2001). Assessment of body change and distress. Retrieved from https://www.fstrf.org/apps/cfmx/apps/common/QOLAdherenceFo $\mathrm{rms} /$ resources/actg/forms/english/q10725.pdf

Peterson, S., Martins, C. R., \& Cofrancesco, J. R. (2008). Lipodystrophy in the patient with HIV: Social, psychological, and treatment considerations. Aesthetic Surgery Journal, 28(4), 443-51. http://doi.org/10.1016/j.asj.2008.04.009

Sanches, R. S., Mill, J., Machado, A. A., Donadi, E. A., \& Morais Fernandes, A. P. (2009). Facial lipoatrophy: Appearances are not deceiving. Journal of the Association of Nurses in AIDS Care, 20(3), 169-175. http://doi.org/10.1016/j.jana.2009.01.002

Sánchez-López, M. P., \& Dresch, V. (2008). The 12-item General Health Questionnaire (GHQ-12): Reliability, external validity and factor structure in the Spanish population. Psicothema, 20(4), 839-843.

Sanjuán, P., Molero, F., Fuster, M. J., \& Nouvilas, E. (2013). Coping with HIV related stigma and well-being. Journal of Happiness Studies, 14, 709722. http://doi.org/10.1007/s10902-012-9350-6 
Schmitt, M. T., Branscombe, N. R., Postmes, T., \& Garcia, A. (2014). The consequences of perceived discrimination for psychological well-being: A meta-analytic review. Psychological Bulletin, 140(4), 921-48. http://doi.org/10.1037/a0035754

Smit, P. J., Brady, M., Carter, M., Fernandes, R., Lamore, L., Meulbroek, M., ... Thompson, M. (2012). HIV-related stigma within communities of gay men: A literature review. AIDS Care, 24(4), 405-412. http://doi.org/10.1080/09540121.2011.613910

Stutterheim, S. E., Bos, A. E. R., Pryor, J. B., Brands, R., Liebregts, M., \& Schaalma, H. P. (2011). Psychological and social correlates of HIV status disclosure: The significance of stigma visibility. AIDS Education and Prevention,

$23(4)$

382-392. http://doi.org/10.1521/aeap.2011.23.4.382

UNAIDS. (2008). Stigma Index: An index to measure the stigma and discrimination experienced by people living with HIV. Retrieved from http://www.stigmaindex.org

Waters, L., \& Nelson, M. (2007). Long-term complications of antiretroviral therapy: Lipoatrophy. International Journal of Clinical Practice, 61(6), 999_ 1014. http://doi.org/10.1111/j.1742-1241.2007.01385.x

(Article received: 28-12-2016; revised: 20-06-2017; accepted: 04-07-2017) 